\title{
SCIENTOMETRIC REVIEW OF RESEARCH TRENDS ON PUBLIC PRIVATE PARTNERSHIP (PPP) FOR INFRASTRUCTURE PROJECTS FROM 2000 TO 2020
}

\author{
Nguyen Van Tam ${ }^{1 *}$ \\ ${ }^{1}$ Faculty of Construction Economics and Management, National University of Civil Engineering, \\ Hanoi, 10000, Vietnam
}

(Received: March 2021 / Revised: March 2021 / Accepted: May 2021)

\begin{abstract}
In the construction industry, public-private partnership (PPP) has been becoming increasingly common. While real-world PPP for infrastructure projects have been reported in many journals, published work on systematically summarizing what they have already provided remains limited. Based on the 1749 publications on PPP for infrastructure collected from the Scopus database for the period of 2000-2020, this study conducted a scientometric analysis in terms of annual publications, regional distribution, active contributors, published journals, co-occurrence keywords, and main research themes of previous studies. This paper found that there was a significant increase in the number of publications on PPP for infrastructure since 2008. Researchers from the USA, China, and Australia have been the main contributors to this research area. In addition, four main themes of research on PPP for infrastructure are explored, and several research gaps and research directions in this area are established for further studies.
\end{abstract}

Keywords: PPP; infrastructure project; scientometric; analysis; network

\section{INTRODUCTION}

Internationally, the use of public-private partnership (PPP) as a strategy for implementing infrastructure projects is well known. In the last few decades, the use of PPP as a major method of delivering infrastructure projects has grown significantly (Al-Saadi \& Abdou, 2016; Alfen et al., 2009; Li et al., 2005). PPP is a strategy for the economic value of infrastructure outputs, and it covers a wide range of public-sector infrastructure (Cui et al., 2018). Access to private funding for expanding services; better risk management and allocation; clearer project objectives; new concepts and flexibility; better preparation and increased incentives for competitive tendering; and greater value for money for infrastructure projects can all be demonstrated in terms of the PPP approach's planned benefits (Al-Saadi \& Abdou, 2016). There has been a proliferation of schemes encouraging public-private sector collaboration to improve infrastructure through a broad variety of economic activities (Ullah et al., 2016). PPP agreements have been adopted by governments in many countries. Concerns over government spending are one explanation for this trend. These structures are viewed as a key component of modernizing public services, with the aim of improving their quality and performance (Carbonara et al., 2014).

Along with the rapid growth in PPP applications, research interest in the field has exploded in the last two decades, resulting in a substantial increase in the number of published papers as well as a wide range of research subjects, domains, and methods.

*Corresponding author's email: tamnv2@nuce.edu.vn, Tel. (+84) 904559957

DOI: https://doi.org/10.32783/csid-jid.v4i1.215 
As the academic research on PPP for infrastructure has grown, researchers have been able to share research results and examine the status quo and trends in PPP practice. As a result, this review of scientific papers published in academic journals will aid researchers in discovering the current status and future trends of the chosen topics in this domain (Cui et al., 2018; Yongjian Ke et al., 2009; Osei-Kyei \& Chan, 2015).

Further studies will benefit from the integration and classification of published literature reviews within the PPP for infrastructure domain because it will enable them to gain a better understanding of the subject and perform related research more intensively and efficiently. Hence, it is critical to summarize the global trends of PPP for infrastructure through comprehensive analysis and to propose new research directions. In this regard, this paper performs a systematic analysis of studies on PPP for infrastructure in the years from 2000 to 2020 with the following derived objectives:

- To ascertain the annual publication trends of PPP for infrastructure from 2000 to 2020

- To identify countries with the most published papers on PPP for infrastructure from 2000 to 2020

- To identify author's contribution in studying PPP for infrastructure from 2000 to 2020

- To summarize, compare, and contrast the key findings of publications on PPP for infrastructure from 2000 to 2020

\section{RESEARCH METHODOLOGY}

This paper aims to comprehensively review PPP for infrastructure in the scientific literature by using scientometric analysis. The author uses VOSviewer software based on the bibliographic data collected from Scopus. In this study, the scientometric review was done using the science mapping technique. This method is commonly used for domain analysis and visualization of important patterns and trends in the body of knowledge (Chen, 2017; Cobo et al., 2011). It gives valuable information about the research context in the field of consideration (Cheng et al., 2018; L. Zheng et al., 2019).

One of the decisions researchers must make when conducting an overview of a science area, such as this paper, is which scientific databases to use (Olawumi \& Chan, 2018). Scopus, ISI Web of Science, Dimensions, Google Scholar, and Research Gate are the main research databases. Because of extensive coverage of high-quality peer-reviewed papers, stringent inclusion criteria and indexing procedure, and availability of more recent publications, the Scopus database was chosen for identifying relevant literature on PPP for infrastructure in this study (Zhao et al., 2019). The search string, a systematic literature search, retrieval, and indexing were performed on Scopus search engine or database using the search query "PPP" and "infrastructure" or "public-private partnership" and "infrastructure" in the "title/abstract/keyword" section of published studies. The preliminary search was not limited to a particular country and no year limitation; the output was 3,079 publications.

Next, the "source title" has been used to refine to be considered during the period between 2000 and 2020; and only articles and reviews written in English were chosen. Final, to ensure that the findings of the literature review were systematic and accurate, the literature consulted was limited to articles, excluding book reviews, letters, news reports, and conference abstracts. This is because journal articles are generally peer-reviewed and are believed to provide more detailed, robust, and high-quality knowledge than other forms of publications ( $\mathrm{Z}$. Liu et al., 2019). In total, 1749 publications on PPP for infrastructure were collected after refinement and duplicate testing, and all bibliographic material was exported from Scopus, forming the dataset for further analysis in this study. Figure 1 illustrates the research framework for this study. 


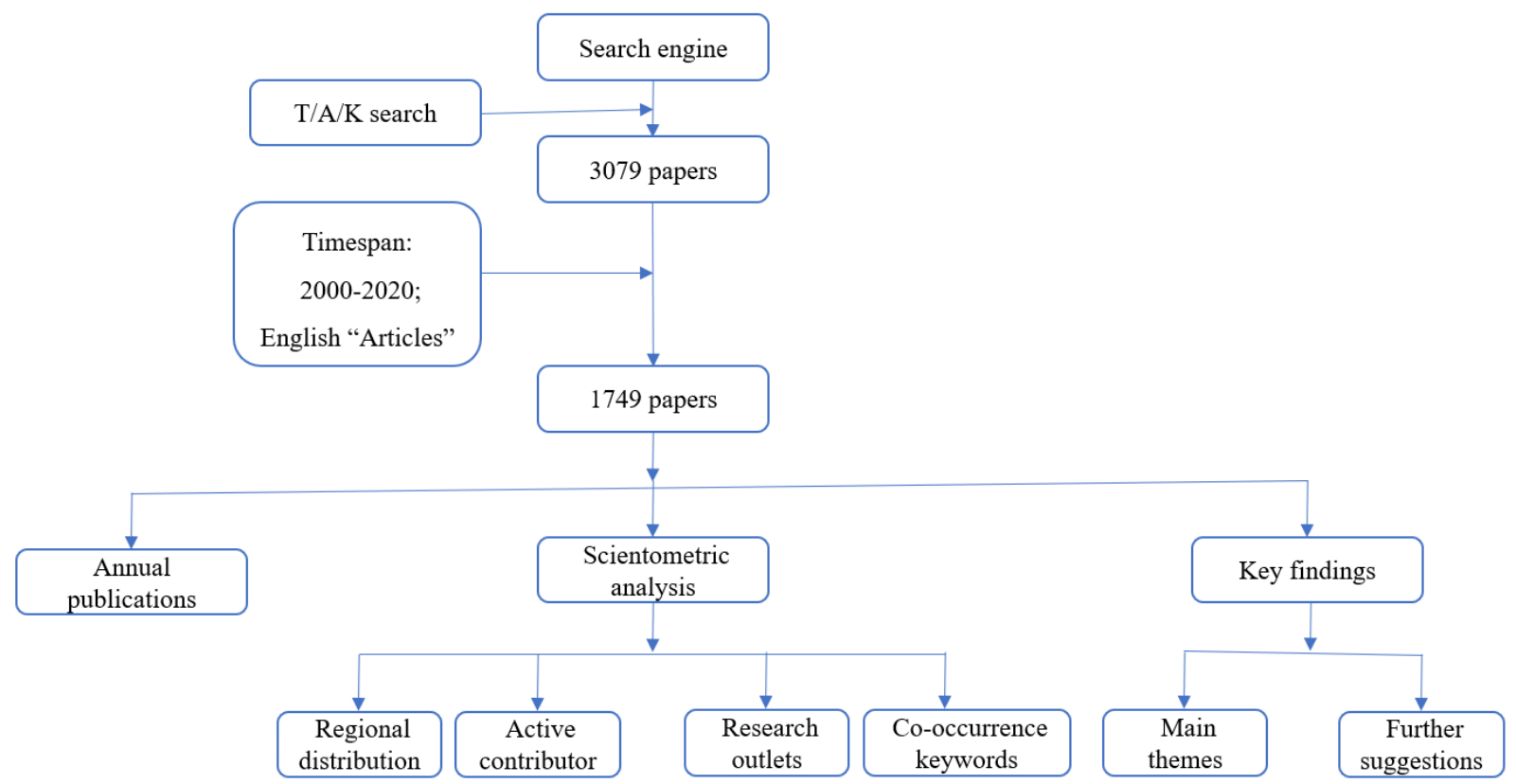

Note: $T / A / K$-title/ abstract/ keywords

Figure 1 The research framework for the study

\section{RESULT AND DISCUSSION}

\subsection{Annual Publications on PPP for Infrastructure from 2000 to 2020}

The temporal distribution of all 1749 publications on PPP for infrastructure obtained from the Scopus database is provided in Figure 2. The number of research publications related to PPP for infrastructure has increased steadily in the years 2000-2020, with a sharp increase particularly since 2018. This proves the gradual rising of interest in exploring the best ways of delivering PPP for infrastructure projects since its evolution. Furthermore, the findings statistics support the claim that PPP for infrastructure research is one key domain of interest to academic researchers (Yongjian Ke et al., 2009; Tang et al., 2010).

A total of 1578 papers on PPP for infrastructure were published in the period of 2008-2020. These figures are also unsurprising because, after the global economic crisis of 2008, many governments were pressured to introduce PPP policies, causing a greater emphasis on how this strategy could be applied efficiently and successfully to reduce a country's infrastructure deficit (Kappeler \& Nemoz, 2010). It is important to note that the pattern of increased research on PPP for infrastructure will continue, as more policymakers embrace and adopt this approach as a result of its success in other jurisdictions (Junxiao Liu et al., 2015). Furthermore, the number of PPP for infrastructure projects is rising around the world, which will certainly stimulate more research into this field in order to implement potential projects. 


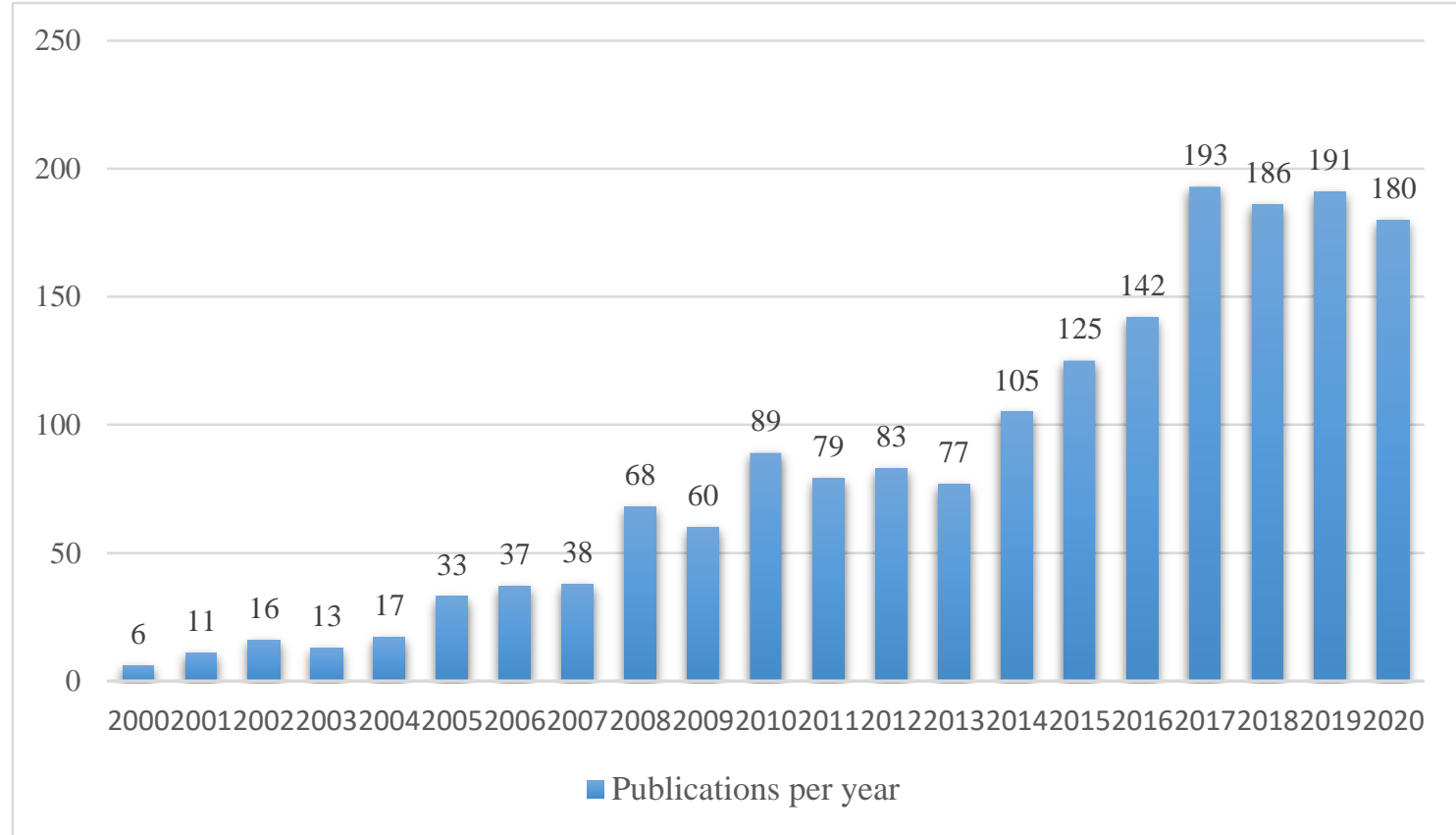

Figure 2 Annual publication on PPP for infrastructure research from 2000 to 2020

\subsection{Regional Distribution of PPP for Infrastructure Research from 2000 to 2020}

The country/territory details in papers on PPP for infrastructure can be found in the published bibliographic records, enabling the key country/territory of the publications to be determined. 1749 PPP for infrastructure papers is written in 139 countries/ territories, according to Scopus database. Table 1 lists the top ten most active countries/territories in this are research. In terms of the overall volume of PPP for infrastructure papers, publications in the Top 10 countries/territories accounted for roughly 78 percent of the total volume. The top three nations, the USA, China, and Australia, each contributed 361, 180, and 172 articles, accounting for nearly half of the total number. This implies a widespread knowledge of PPP among researchers in these countries due to their well-implemented and well-developed PPP policy (Osei-Kyei \& Chan, 2015).

Setting the minimum number of country documents and citations to 5 and 12, respectively, generated Figure 3 . Of the 139 construction productivity research countries, 55 met the thresholds. It should be noted that the USA node was the biggest, implying that the USA academics were the primary contributors to the analysis of PPP for infrastructure.

In the years 2000-2020, China, India, and Hong Kong, three Asian countries/territories in the Top 10, accounted for roughly $30 \%$ of all publications in this domain. There were 152 publications in the United Kingdom, 104 publications in the Russian Federation, 59 publications in Italy, and 58 publications in Spain, accounting for approximately $21 \%$ of all publications in Europe. In North America, 361 papers were published in the United States and 86 in Canada, accounting for roughly $26 \%$ of the number. Australian academics published 172 papers in Oceania, accounting for approximately $10 \%$ of the number in this are research. 
Table 1 Most contributing country/territory on PPP for infrastructure research from 2000 to 2020

\begin{tabular}{ccccc}
\hline Country & Documents & Citations & Ave. Citations & Total link strength \\
\hline United States & 361 & 3895 & 10.79 & 46854 \\
China & 180 & 2957 & 16.43 & 57795 \\
Australia & 172 & 3932 & 22.86 & 59124 \\
United Kingdom & 152 & 2738 & 18.01 & 35299 \\
India & 127 & 756 & 5.95 & 16114 \\
Russian Federation & 104 & 227 & 2.18 & 3392 \\
Canada & 86 & 1175 & 13.66 & 12276 \\
Hong Kong & 67 & 2261 & 33.75 & 31663 \\
Italy & 59 & 658 & 11.15 & 13204 \\
Spain & 58 & 559 & 9.64 & 14176 \\
\hline
\end{tabular}

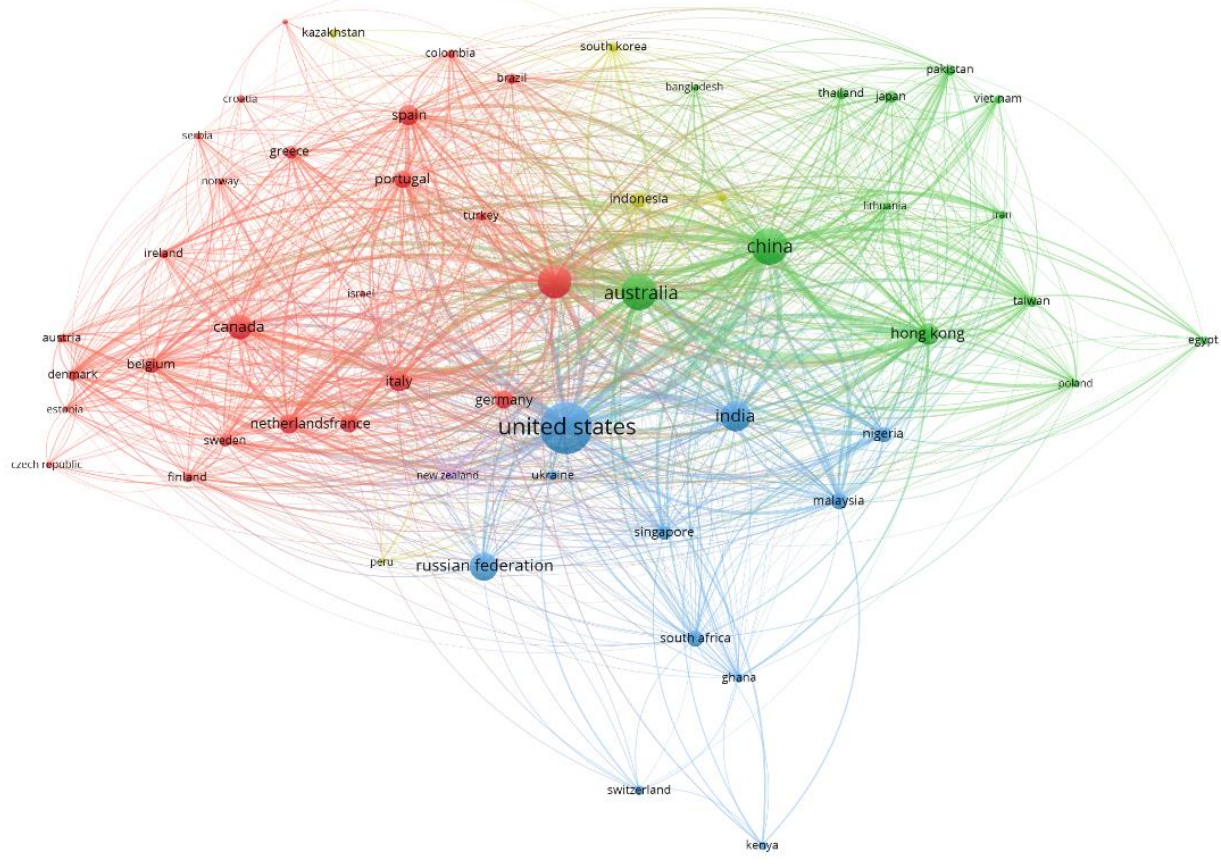

Figure 3 Country/territory distribution of on PPP for infrastructure research from 2000 to 2020

\subsection{Active Contributors to PPP for Infrastructure Research from 2000 to 2020}

According to the Scopus database, a total of 3,684 authors participated in PPP for infrastructure studies. The minimum number of publications and citations for each author has been set at 5 and 13; as a result, 54 of the researchers meet the threshold. The density visualization of the most productive authors network was shown in Figure 4. The diversity in the location of published authors shows that PPP for infrastructure research is global. The network shows the authors have published the highest publications on this domain such as Chan, A.P.C, Marques, R.C., and Liu, J. who are often researchers with influential works in PPP for infrastructure research domain. 
Table 2 Authors with highest publications on PPP for infrastructure research from 2000 to 2020

\begin{tabular}{ccccc}
\hline Author & Documents & Citations & Ave. Citations & Total link strength \\
\hline Chan, A.P.C & 26 & 1122 & 43.15 & 11506 \\
Marques, R.C. & 20 & 711 & 35.55 & 3613 \\
Liu, J. & 19 & 515 & 27.11 & 11864 \\
Smith, J. & 17 & 503 & 29.59 & 13584 \\
Love, P.E.D. & 17 & 538 & 31.65 & 13350 \\
Cruz, C.O. & 16 & 430 & 26.88 & 2849 \\
Zhang, L. & 14 & 94 & 6.71 & 2245 \\
Zhang, X. & 14 & 987 & 70.50 & 1475 \\
Siemiatycki, M. & 14 & 362 & 25.86 & 2529 \\
\hline
\end{tabular}

This finding was supported by the result statistics in Table 2, Chan, A.P.C is the most productive researcher on PPP for infrastructure area, with 26 publications and 1122 times cited, representing average normalized citation is 41.15 for each publication. Followed by Marques, R.C., and Liu, J. at 20 and 19 publications, respectively. Besides, 7 other researchers published at least 14 publications on PPP for infrastructure research area.

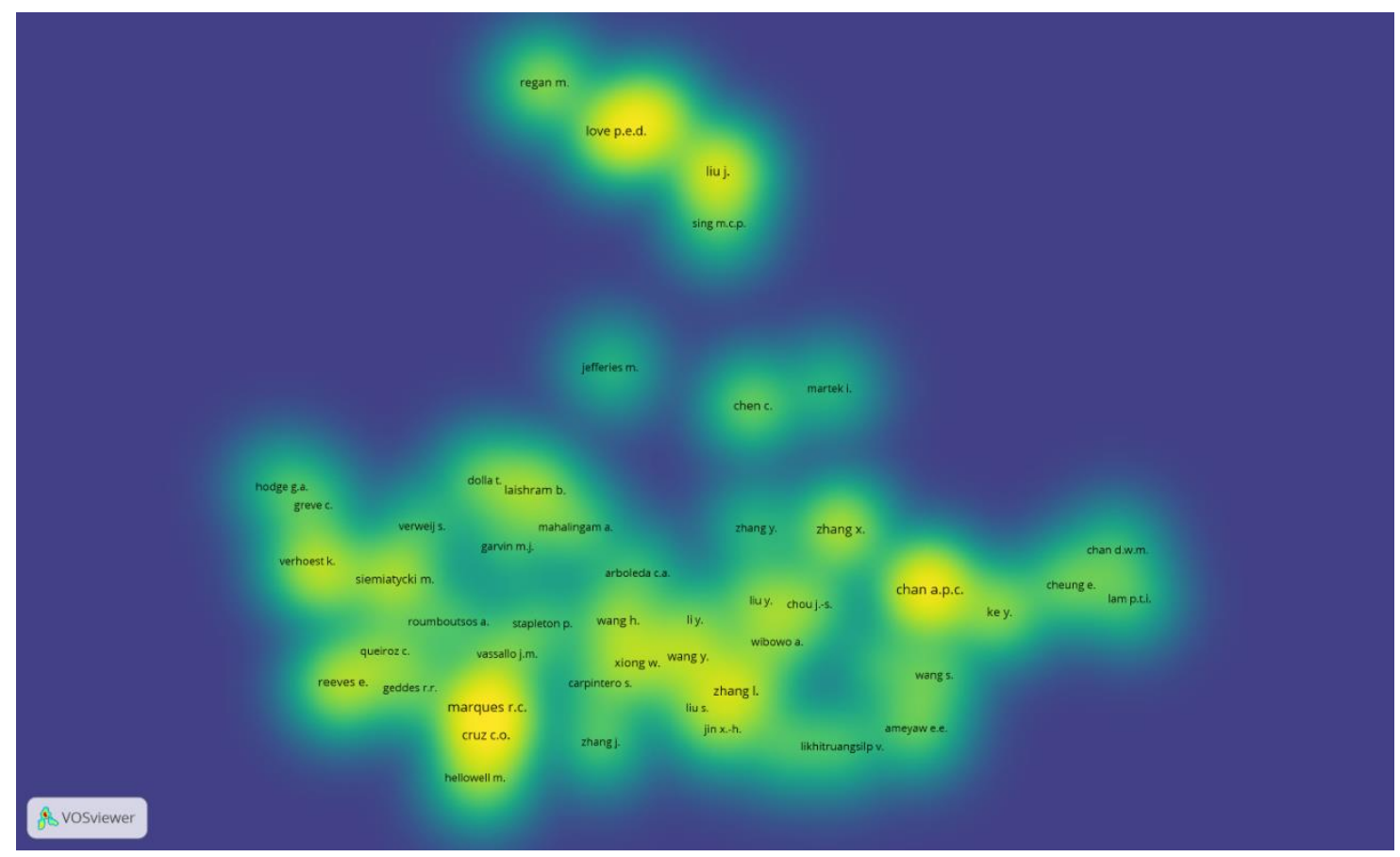

Figure 4 Most productive authors

The analysis was further used to highlight the affiliated authors' institutions. The exercise summarized the contribution of the various institutions to the development of the PPP or infrastructure during the study period. As provided in Table 3, Hong Kong Polytechnic University, Universidade de Lisboa, and Curtin University are leading the race with 36, 31, and 27 publications, respectively. 
Table 3 Organizations with highest publications on PPP for infrastructure research from 2000 to 2020

\begin{tabular}{lc}
\hline \multicolumn{1}{c}{ Affiliation } & Publications \\
\hline Hong Kong Polytechnic University & 36 \\
Universidade de Lisboa & 31 \\
Curtin University & 27 \\
Instituto Superior Técnico & 26 \\
Universiteit Antwerpen & 21 \\
University of Melbourne & 21 \\
University of Toronto & 19 \\
Universidad Politécnica de Madrid & 17 \\
Bond University & 17 \\
The University of Hong Kong & 16 \\
\hline
\end{tabular}

\subsection{Science Mapping of Academic Journals}

Academic journals play an important role in the dissemination of research outcomes, hence, in the review of the research trend, and it is essential that prominent research journals in the domain are discovered. It is not a matter of promoting journals, but of informing researchers of leading outlets and platforms to disseminate the findings of their research in order to achieve maximum impact in both academia and industry (Osei-Kyei et al., 2020). The top 10 journals/proceedings in the area of PPP for infrastructure research are presented in Table 4. In addition, a network analysis of these prominent journals/proceedings is shown in Figure 5 which illustrates 34 journals/proceedings with a minimum of 5 articles and 10 citations among 146 different sources from the retrieved Scopus database. Indeed, the large number of journals identified clearly show how relevant PPP has become to infrastructure issues in contemporary times.

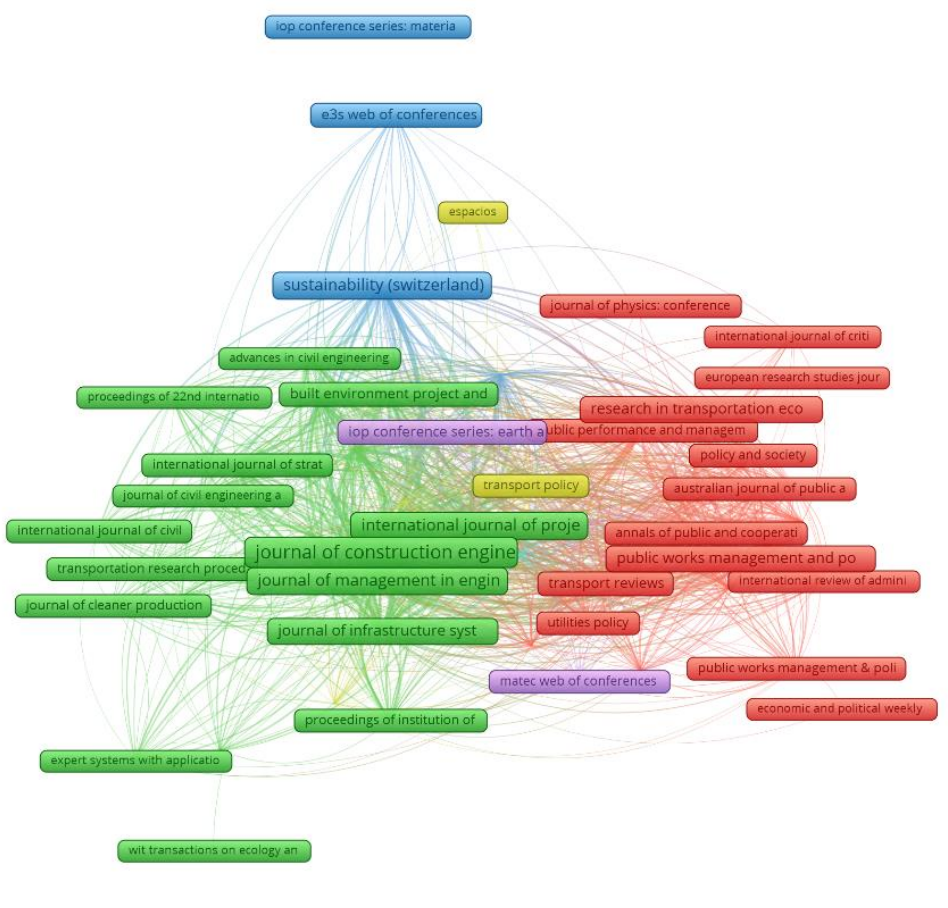

Figure 5 Network of landmark research outlets in PPP for infrastructure research from 2000 to 
As demonstrated in Table 4, Journal of Construction Engineering and Management has produced the highest number of articles on issues relating to PPP for infrastructure area, with 41 publications cited 2422 times, representing 50.97 citations per paper. It is followed by International Journal of Project Management, Sustainability (Switzerland), and Journal of Management in Engineering with 28, 26, and 25 publications, in turn. It should be noted that the articles retrieved for this analysis are only those related to the infrastructure PPP as used in the search engine. However, the results are an indication of the leading journals/proceedings in this field and its associated research areas.

Table 4 Most frequently publication journals/proceedings PPP for infrastructure research from 2000 to 2020

\begin{tabular}{lcccc}
\hline \multicolumn{1}{c}{ Source } & Documents & Citations & $\begin{array}{c}\text { Ave. } \\
\text { Citations }\end{array}$ & $\begin{array}{c}\text { Total link } \\
\text { strength }\end{array}$ \\
\hline Journal of Construction Engineering and & 41 & 2422 & 59.07 & 5466 \\
Management & 28 & 2084 & 74.43 & 5678 \\
International Journal of Project Management & 26 & 179 & 6.88 & 3315 \\
Sustainability (Switzerland) & 25 & 723 & 28.92 & 6315 \\
Journal of Management in Engineering & 21 & 394 & 18.76 & 4111 \\
Journal of Infrastructure Systems & 19 & 157 & 8.26 & 2299 \\
$\begin{array}{l}\text { Public Works Management and Policy } \\
\text { Advances in Public Private Partnerships }\end{array}$ & 18 & 7 & 0.39 & 1018 \\
$\begin{array}{l}\text { Proceedings of the 2nd International } \\
\text { Conference on Public Private Partnerships }\end{array}$ & 16 & 222 & 13.88 & 532 \\
$\begin{array}{l}\text { Research in Transportation Economics } \\
\text { Engineering Construction and Architectural }\end{array}$ & 15 & 265 & 17.67 & 2828 \\
$\begin{array}{l}\text { Management } \\
\text { IOP Conference Series Earth and }\end{array}$ & 15 & 275 & 18.33 & 2691 \\
$\begin{array}{l}\text { Environmental Science } \\
\text { Journal of Financial Management of }\end{array}$ & 15 & 10 & 0.67 & 578 \\
$\begin{array}{l}\text { Property and Construction } \\
\text { Built Environment Project and Asset }\end{array}$ & 14 & 169 & 12.07 & 1956 \\
Management & & & & \\
\hline
\end{tabular}

\subsection{Co-occurrence Network of Keywords}

The keywords of the academic paper reflect its core content and the development of research topics can be achieved through a bibliometric analysis of these keywords (C. Zheng et al., 2020). As shown in Figure 5, each keyword node consists of cross-rings, and the rings and links are indicated in a spectrum of colors corresponding to the years of the keywords during the period under study. 1749 considered PPP for infrastructure documents contain a total of 8242 keywords and the minimum occurrences of keywords were set to 15 to avoid the visualizing of less relevant keywords. Only 163 keywords meet the set threshold, and these were visualized in Figure 6.

It is evident that "public-private partnerships" was the largest point of the research direction, showing that this keyword was mostly used in this field. In addition, the details of keywords that have frequently occurred in the analyzed documents illustrated in Table 5. According to the occurrences of the keywords, we can be aware that "infrastructure", "PPP", and "public private partnership" were also included in the popular research topics. Awareness of the most active 
keywords should guide researchers on the appropriate keywords to be used in their articles in order to facilitate wider indexing and retrieval of articles.

Table 5 Most active keywords in PPP for infrastructure research

\begin{tabular}{ccc}
\hline Keyword & Occurrences & Total link strength \\
\hline public-private partnerships & 199 & 250 \\
infrastructure & 158 & 341 \\
PPP & 93 & 159 \\
public private partnership & 80 & 100 \\
public private partnerships & 47 & 78 \\
public-private partnerships & 46 & 81 \\
procurement & 45 & 127 \\
public-private partnership (PPP) & 45 & 53 \\
partnership & 39 & 103 \\
risk management & 36 & 88 \\
china & 36 & 83 \\
infrastructure projects & 33 & 65 \\
governance & 32 & 70 \\
developing countries & 30 & 59 \\
public-private partnership & 30 & 40 \\
India & 29 & 54 \\
risk allocation & 27 & 64 \\
partnerships & 25 & 90 \\
private sector & 25 & 79 \\
\hline
\end{tabular}

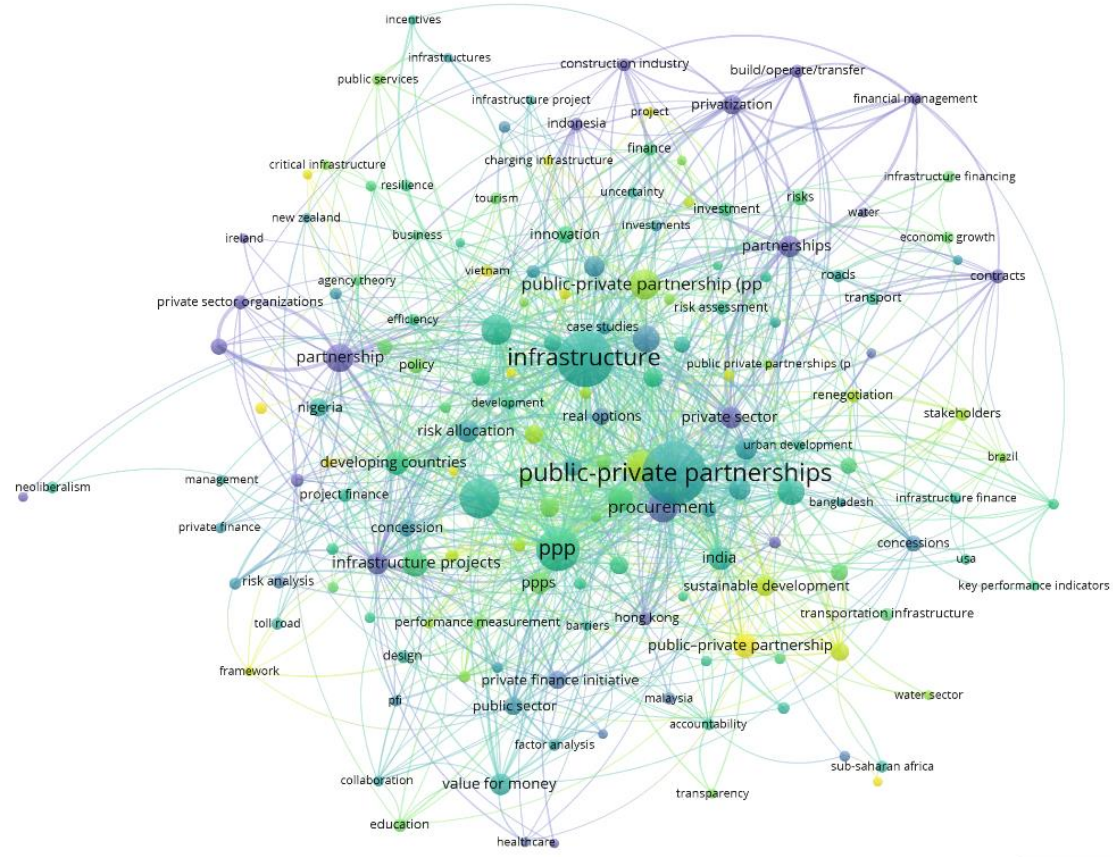

Figure 6 Co-occurrence network of keywords 


\subsection{Main Research Themes of PPP for Infrastructure}

This section will discuss the emerging domains and themes in PPP for infrastructure research. The themes were derived by analyzing the abstracts of the analyzed articles as well as the checklist of keywords derived from the bibliometric data. As a result, four main themes of research on PPP for infrastructure were identified as follows:

\subsubsection{Research on success factors of PPP for infrastructure projects}

Since the evolution of PPP, researchers have used the concept of success factors to improve understanding and best ways to implement PPP policies for infrastructure development (Aerts et al., 2014; Cheung et al., 2012; Chou \& Pramudawardhani, 2015; Hwang et al., 2013; Jefferies, 2006; Y Ke et al., 2009; Li et al., 2005; Junxiao Liu et al., 2015; Olusola Babatunde et al., 2012; Tiong et al., 1992; Zhang, 2005). In fact, attention has also been paid to developed and developing countries using PPP policies to support infrastructure growth; critical success factors (CSFs) for implementing PPP projects in these countries have also been explored by researchers (Osei-Kyei \& Chan, 2015).

For instance, the study of Cheung et al. (2012) analyzed the perceptions of respondents from Hong Kong, Australia, and the UK on the importance of 18 success factors which contribute to delivering successful PPP projects. This comparison showed that amongst the top five success factors ranked by Hong Kong respondents, three were also ranked highly by the Australians and British. These success factors included: "Commitment and responsibility of public and private sectors"; "Strong and good private consortium"; and "Appropriate risk allocation and risksharing". Therefore, it can be concluded that there are certain common critical success factors for conducting PPP projects, irrespective of the geographical locations. Meanwhile, Hwang et al. (2013) identified the critical risk factors and preferred risk allocations for PPP projects in Singapore. This indicated that negative factors were more affirmative than positive factors and that 23 risk factors had significant criticalities. Eight risks would be preferably allocated to the public sector while 19 risks could be assigned to the private sector. 11 risks were preferred to be shared by both parties and the allocation of four risks depended on project circumstances.

The study from Tiong et al. (1992) indicated the importance and characteristics of CSFs that are vital for project sponsors in their endeavors to win lucrative BOT contracts. These factors are entrepreneurship, picking the right project, a strong team of stakeholders, an imaginative technical solution, a competitive financial proposal, and the inclusion of special features in the bid. However, 46 CSFs were identified, analyzed, and categorized into five main CSFs by Zhang (2005), including (1) favorable investment environment, (2) economic viability, (3) reliable concessionaire consortium with strong technical strength, (4) sound financial package, and (5) appropriate risk allocation via reliable contractual arrangements. Based on comprehensive review, Osei-Kyei and Chan (2015) found that several factors account for successful PPP projects however the top most five factors are appropriate risk allocation and sharing, strong private consortium, political support, community/public support and transparent procurement.

\subsubsection{Research on risks of PPP for infrastructure projects}

Risk research can help to explore the appropriate ways to manage the significant risks associated with PPPs for infrastructure projects (Tang et al., 2010). Hence, this domain has been attracted many studies to date (Abednego \& Ogunlana, 2006; Alonso-Conde et al., 2007; C. Ameyaw et al., 2015; E. E. Ameyaw \& Chan, 2015; Boeing Singh \& Kalidindi, 2006; Chang \& Ko, 2017; Effah Ameyaw \& Chan, 2013; Grimsey \& Lewis, 2002; Ibrahim et al., 2006; Iyer 
\& Sagheer, 2012; Pellegrino et al., 2013; Shen \& Wu, 2005; Thomas et al., 2006; Trangkanont \& Charoenngam, 2014; Xu et al., 2010; Zayed \& Chang, 2002). Risks in PPPs may be grouped according to the conventional risk management process: identification of risk areas, risk analysis and risk strategies.

A risk probability and impact assessment framework based on fuzzy-fault tree and the Delphi method is proposed by Thomas et al. (2006). The framework includes extensive scenario modeling of critical risks in projects and the systematic processing of professional judgment by experts and is developed and demonstrated in the context of critical risks in Indian BOT road projects. Another more recent technique is a fuzzy synthetic assessment approach, which is becoming increasingly popular as a means of assessing the level of risk (C. Ameyaw et al., 2015; Xu et al., 2010). Grimsey and Lewis (2002) analyzed principles involved, drawing on the practical experience of evaluating infrastructure projects to present a framework for assessing the risks, and using as illustration a case study of a waste water treatment facility in Scotland which is typical of most PPP projects. The key risks common to many PPP projects that have an impact on revenue are traffic revenue risk, operating risk, demand risk, and debt servicing risk (Boeing Singh \& Kalidindi, 2006), while the impacting costs include overruns of financing, construction and operating costs (Ibrahim et al., 2006).

As far as risk assessment methods are concerned, the most widely used technique is the application of a risk register matrix, which includes the specific impact and probability of occurrence of each identified risk. This can be considered alongside a two-dimensional value curve including performance versus value (Zayed \& Chang, 2002). Strategies adopted by project managers generally depend on the predictability of the risk impact and the controllability of the risk outcome (Trangkanont \& Charoenngam, 2014). Based on the identification and allocation of the main risks embedded in the project during the initial phase of the project (planning and design), decision-makers can easily find a cost-effective way to control risk and maximize investment value in an optimal way (Pellegrino et al., 2013). In addition, the Monte Carlo method is used as an effective tool for simulating indeterminacy during construction and concession periods (Alonso-Conde et al., 2007; Chang \& Ko, 2017; Wibowo \& Alfen, 2013).

\subsubsection{Research on financing of PPP for infrastructure projects}

Financing plays a key role in the PPP projects. Research focusing on model development addressed different financing issues (Cheung et al., 2012; Hwang et al., 2013; Jefferies, 2006; Yongjian Ke et al., 2010; Li et al., 2005; Junying Liu et al., 2015; Olusola Babatunde et al., 2012; Tiong et al., 1992; Zhang, 2005). Since 2000, related articles have paid more attention to the detailed issues in the financial package (Cui et al., 2018). Many studies have been tried to research the financial viability of PPP infrastructure projects (Akintoye et al., 2003; Fantozzi et al., 2014; Grimsey \& Lewis, 2004, 2005; Ho \& Liu, 2002; Iyer \& Sagheer, 2012; Schaufelberger \& Wipadapisut, 2003; Smith et al., 2004). For instance, Ho and Liu (2002) used an option-based pricing model to assess the financial viability of a privatized infrastructure project. In order to estimate when the project is at risk of bankruptcy, this quantitative model takes into account the views of the project promoter and the government. The literature was reviewed and qualitative analysis was used to examine factors that could continue to challenge the achievement of best value was undertaken by Akintoye et al. (2003). They found that, among other things, the high cost of the PFI procurement process is a key factor, which is a burden on the PPP project, leading to a reduction in the willingness of the private sector to participate. 
The study of Smith et al. (2004) analyzed the negotiation, construction and operation phases of the Huaibei Power Plant Project in China and found that the development of PPP markets depends on whether the PPP payment mechanism can be properly managed as an incentive. Schaufelberger \& Wipadapisut (2003) explained that the availability of funding significantly influenced the selection of a favorable financing strategy. Such a strategy can support the participation of the private sector.

\subsubsection{Research on relationship among parties of PPP for infrastructure projects}

Relationships between public and private sector organizations are seen as crucial to the success of PPPs in infrastructure projects, because poor relations would easily lead to misunderstandings and conflict (Tang et al., 2010). In some projects, there is a discrepancy between the complicated governance approach and the relatively straightforward infrastructures that have been developed, which has led to the argument that a better sense of contingency is needed in future PPP programs (van den Hurk \& Verhoest, 2015). Therefore, many researchers have examined what factors facilitate or inhibit the relationship between PPP infrastructure project's parties (Abdul-Aziz, 2001; Chan et al., 2003; Consoli, 2006; Erridge \& Greer, 2002; E. Palaneeswaran \& Kumaraswamy, 2000; Ekambaram Palaneeswaran \& Kumaraswamy, 2000; Smyth \& Edkins, 2007; van den Hurk \& Verhoest, 2015; Ysa, 2007; Zhang, 2004b, 2004a).

The study of Chan et al (2003) found that "improved relationship between project participants" and "improved communication between project participants" were the most significant benefits from the use of partnering in PPP projects. Abdul-Aziz (2001) argued that, once privatization has taken place, the re-involvement of the public sector, in particular through the injection of new funds, should be avoided as much as possible due to the lack of expert experience and the potential social impact of the project. However, Consoli (2006) found that different stakeholder demands, contractual arrangements and philosophic points of view created friction between the parties involved. Apparently, friction is the main course of poor relations. Researchers also related the issue of the contractor selection relationship. In selecting suitable contractors, researchers have not only suggested benchmarking of 'best' selection practices, but have also emphasized "innovative" approaches to selecting contractors to be used by large public clients, in which the relationship is always seen as a key criterion (E. Palaneeswaran \& Kumaraswamy, 2000; Ekambaram Palaneeswaran \& Kumaraswamy, 2000; Zhang, 2004a, 2004b).

\section{FUTURE STUDY SUGGESTIONS}

The existing body of literature on PPP for infrastructure studies has allowed for advancements in PPP infrastructure projects practice. Nonetheless, there are some flaws and challenges in PPP theory and practice when it comes to infrastructure projects. The review of the PPP for infrastructure studies provided insights into the design of future research agendas. The following discussion, therefore, recommends a number of possible further research in this domain.

\subsection{Social and Environmental Impact Assessment for PPP Models Development}

The impact level of the social and environmental issues should be established, particularly when relating to different PPP types, for PPP projects to run smoothly. PPP decision models can be developed using both empirical and operational studies. Conceptual models can be established empirically based on case studies and validated with a representative sample. Furthermore, a suitable decision-making methodology should be used to set up a decision 
model for estimating the specific impact level of social and environmental problems on a specific PPP infrastructure project.

\subsection{Performance Evaluation Criteria for PPP Projects Long-term Viability}

There are still no structured, systemic, or operational mechanisms in place to assess whether PPP outputs are sustainable over a long-term contractual period (Junxiao Liu et al., 2016). Improving the sustainability efficiency of PPP infrastructure projects should be a top priority. Hence, it should be encouraged academic researchers have focused on enhancing economic, social, and environmental performance standards in assessing project viability through sustainability performance assessment of infrastructure PPP projects. Furthermore, parties of PPP infrastructure projects should launch a comprehensive and long-term marketing strategy to ensure that the public can be innovative in developing financial packages and allocating resources to boost PPP efficiency and maintain a competitive edge.

\subsection{Development of Flexible Contractual Agreements}

When it comes to dealing with ambiguity, flexible contracts are more fitting, and they are a sensible solution for PPP ventures. Despite the fact that the terms "flexible contract" and "renegotiation" introduce different alternative methodologies or rules, they are still in their infancy and have a lot of space for development. Since negative behavioral traits may contribute to adversarial or litigious relationships during contract execution, further research is required to evaluate which factors influence conduct. Hence, researchers can incorporate strengths from current methodologies to analyze contract flexibility classification and calculation, as well as flexible contract terms, complex contract supervision, and renegotiation triggers, among other topics.

\section{CONCLUSIONS AND LIMITATIONS}

This study provided a thorough analysis of the status quo, gaps, and research suggestions for the future of PPP research for infrastructure projects, in response to the increasing interest in the research and application of PPP procurement. This paper performed a scientometric analysis based on the literature data of 1749 publications on this domain from the collected Scopus core set for the period 2000-2020. The VOSviewer software was used in this study to identify emerging research-front terms and concepts, as well as pivotal points with high betweenness centralities in research networks in this field.

This paper found that there was a significant increase in the number of publications on PPP for infrastructure since 208. Researchers from the USA, China, and Australia have been the main contributors to this research area through regional analysis. Among the research journals in the field of PPP for infrastructure, the Journal of Construction Engineering and Management is the most published journal in the period from 2000 to 2020, followed by the International Journal of Project Management and Sustainability (Switzerland). The results of co-occurrence analysis of keywords show that public-private partnerships, infrastructure, PPP, and public-private partnership are nodes with both high citation frequency and high centrality.

In addition, four main themes of research on PPP for infrastructure are explored, including research on success factors of PPP for infrastructure projects, research on risks of PPP for infrastructure projects, research on financing of PPP for infrastructure projects and research on relationship among parties of PPP for infrastructure projects. Several research gaps and research directions in this area are established as a result of this. The results can be used to draw some 
conclusions about the current state of PPP for infrastructure research and to help researchers choose potential research topics.

The parameters used in selecting the papers for the analysis are the study's limitations. The study's dataset retrieved from the Scopus search engine and may have been holes in coverage. Since this research was limited, similar studies could be conducted using data from more libraries or search engines, as well as taking into account books and other sources.

\section{REFERENCES}

Abdul-Aziz, A.-R. (2001). Unraveling of BOT Scheme: Malaysia's Indah Water Konsortium. Journal of Construction Engineering and Management, 127(6). https://doi.org/10.1061/(asce)0733-9364(2001)127:6(457)

Abednego, M. P., \& Ogunlana, S. O. (2006). Good project governance for proper risk allocation in public-private partnerships in Indonesia. International Journal of Project Management, 24(7). https://doi.org/10.1016/j.ijproman.2006.07.010

Aerts, G., Grage, T., Dooms, M., \& Haezendonck, E. (2014). Public-private partnerships for the provision of port infrastructure: An explorative multi-actor perspective on critical success factors. Asian Journal of Shipping and Logistics, 30(3). https://doi.org/10.1016/j.ajsl.2014.12.002

Akintoye, A., Beck, M., \& Hardcastle, C. (2003). Introduction: Public-private partnership in infrastructure development. Blackwell Science. http://scholar.google.com/scholar?hl=en\&btnG=Search\&q=intitle:Introduction+:+publicprivate+partnership+infrastructure+development\#2

Al-Saadi, R., \& Abdou, A. (2016). Factors critical for the success of public-private partnerships in UAE infrastructure projects: experts' perception. International Journal of Construction Management, 16(3), 234-248. https://doi.org/10.1080/15623599.2016.1146110

Alfen, H. W., Kalidindi, S. N., Ogunlana, S., Wang, S.-I., Abednego, M. P., Frank-Jungbecker, A., Jan, Y.-C. A., Ke, Y., Liu, Y., Singh, L. B., \& Zhao, G. (2009). Public-Private Partnership in Infrastructure Development: Case Studies from Asia and Europe. Weimar: Verlag der Bauhaus-Universität.

Alonso-Conde, A. B., Brown, C., \& Rojo-Suarez, J. (2007). Public private partnerships: Incentives, risk transfer and real options. Review of Financial Economics, 16(4), 335-349. https://doi.org/10.1016/j.rfe.2007.03.002

Ameyaw, C., Adjei-Kumi, T., \& Owusu-Manu, D. G. (2015). Exploring value for money (VfM) assessment methods of public-private partnership projects in Ghana: A theoretical framework. Journal of Financial Management of Property and Construction, 20(3), 268285. https://doi.org/10.1108/JFMPC-01-2015-0003

Ameyaw, E. E., \& Chan, A. P. C. (2015). Evaluation and ranking of risk factors in publicprivate partnership water supply projects in developing countries using fuzzy synthetic evaluation approach. Expert Systems with Applications, 42(12), 5102-5116. https://doi.org/10.1016/j.eswa.2015.02.041

Boeing Singh, L., \& Kalidindi, S. N. (2006). Traffic revenue risk management through Annuity Model of PPP road projects in India. International Journal of Project Management, 24(7), 605-613. https://doi.org/10.1016/j.ijproman.2006.07.008

Carbonara, N., Costantino, N., \& Pellegrino, R. (2014). Concession period for PPPs: A win-win model for a fair risk sharing. International Journal of Project Management, 32(7), 12231232. https://doi.org/10.1016/j.ijproman.2014.01.007

Chan, A. P. C., Chan, D. W. M., \& Ho, K. S. K. (2003). An empirical study of the benefits of construction partnering in Hong Kong. Construction Management and Economics, 21(5), 523-533. https://doi.org/10.1080/0144619032000056162 
Chang, C.-Y., \& Ko, J.-W. (2017). New Approach to Estimating the Standard Deviations of Lognormal Cost Variables in the Monte Carlo Analysis of Construction Risks. Journal of Construction Engineering and Management, 143(1), 06016006. https://doi.org/10.1061/(asce)co.1943-7862.0001207

Chen, C. (2017). Science Mapping: A Systematic Review of the Literature. Journal of Data and Information Science, 2(2), 1-40. https://doi.org/10.1515/jdis-2017-0006

Cheng, F. F., Huang, Y. W., Yu, H. C., \& Wu, C. S. (2018). Mapping knowledge structure by keyword co-occurrence and social network analysis: Evidence from Library Hi Tech between 2006 and 2017. Library Hi Tech, 36(4), 636-650. https://doi.org/10.1108/LHT-012018-0004

Cheung, E., Chan, A. P. C., \& Kajewski, S. (2012). Factors contributing to successful public private partnership projects: Comparing Hong Kong with Australia and the United Kingdom. Journal of Facilities Management, 10(1), 45-58. https://doi.org/10.1108/14725961211200397

Chou, J. S., \& Pramudawardhani, D. (2015). Cross-country comparisons of key drivers, critical success factors and risk allocation for public-private partnership projects. International Journal of Project Management, 33(5), 1136-1150. https://doi.org/10.1016/j.ijproman.2014.12.003

Cobo, M. J., López-Herrera, A. G., Herrera-Viedma, E., \& Herrera, F. (2011). Science mapping software tools: Review, analysis, and cooperative study among tools. Journal of the American Society for Information Science and Technology, 62(7), 1382-1402. https://doi.org/10.1002/asi.21525

Consoli, G. G. S. (2006). Conflict and managing consortia in private prison projects in Australia - Private prison operator responses. International Journal of Project Management, 24(1), 75-82. https://doi.org/10.1016/j.ijproman.2005.06.007

Cui, C., Liu, Y., Hope, A., \& Wang, J. (2018). Review of studies on the public-private partnerships (PPP) for infrastructure projects. International Journal of Project Management, 36(5), 773-794. https://doi.org/10.1016/j.ijproman.2018.03.004

Effah Ameyaw, E., \& Chan, A. P. C. (2013). Identifying public-private partnership (PPP) risks in managing water supply projects in Ghana. Journal of Facilities Management, 11(2), 152182. https://doi.org/10.1108/14725961311314651

Erridge, A., \& Greer, J. (2002). Partnerships and public procurement: Building social capital through supply relations. Public Administration, 80(3), 503-522. https://doi.org/10.1111/1467-9299.00315

Fantozzi, F., Bartocci, P., D’Alessandro, B., Arampatzis, S., \& Manos, B. (2014). Publicprivate partnerships value in bioenergy projects: Economic feasibility analysis based on two case studies. Biomass and Bioenergy, 66, 387-397. https://doi.org/10.1016/j.biombioe.2014.04.006

Grimsey, D., \& Lewis, M. K. (2002). Evaluating the risks of public private partnerships for infrastructure projects. International Journal of Project Management, 20(2), 107-118. https://doi.org/10.1016/S0263-7863(00)00040-5

Grimsey, D., \& Lewis, M. K. (2004). Public private partnerships: The worldwide revolution in infrastructure provision and project finance. In Public Private Partnerships: The Worldwide Revolution in Infrastructure Provision and Project Finance. https://doi.org/10.4337/9781845423438

Grimsey, D., \& Lewis, M. K. (2005). Are Public Private Partnerships value for money?: Evaluating alternative approaches and comparing academic and practitioner views. Accounting Forum, 29(4), 345-378. https://doi.org/10.1016/j.accfor.2005.01.001

Ho, S. P., \& Liu, L. Y. (2002). An option pricing-based model for evaluating the financial viability of privatized infrastructure projects. Construction Management and Economics, 
20(2), 143-156. https://doi.org/10.1080/01446190110110533

Hwang, B. G., Zhao, X., \& Gay, M. J. S. (2013). Public private partnership projects in Singapore: Factors, critical risks and preferred risk allocation from the perspective of contractors. International Journal of Project Management, 31(3), 424-433. https://doi.org/10.1016/j.ijproman.2012.08.003

Ibrahim, A. D., Price, A. D. F., \& Dainty, A. R. J. (2006). The analysis and allocation of risks in public private partnerships in infrastructure projects in Nigeria. Journal of Financial Management of Property and Construction, 11(3), 149-164. https://doi.org/10.1108/13664380680001086

Iyer, K. C., \& Sagheer, M. (2012). Optimization of Bid-Winning Potential and Capital Structure for Build-Operate-Transfer Road Projects in India. Journal of Management in Engineering, 28(2), 104-113. https://doi.org/10.1061/(asce)me.1943-5479.0000071

Jefferies, M. (2006). Critical success factors of public private sector partnerships: A case study of the Sydney SuperDome. Engineering, Construction and Architectural Management, 13(5), 451-462. https://doi.org/10.1108/09699980610690738

Kappeler, A., \& Nemoz, M. (2010). Public-Private Partnerships in Europe-Before and During the Recent Financial Crisis. Economic and Financial Report, European Investment Bank, July, 30.

Ke, Y, Lam, P., Chan, A., Cheung, E., \& Chan, D. (2009). Privileges and attractions for private sector involvement in PPP projects. In Challenges, Opportunities and Solutions in Structural Engineering and Construction. https://doi.org/10.1201/9780203859926.ch123

Ke, Yongjian, Wang, S., Chan, A. P., \& Cheung, E. (2009). Research Trend of Public-Private Partnership in Construction Journals. Journal of Construction Engineering and Management, 135(10), 1076-1086. https://doi.org/10.1061/(asce)07339364(2009)135:10(1076)

Ke, Yongjian, Wang, S. Q., \& Chan, A. P. C. (2010). Risk allocation in public-private partnership infrastructure projects: Comparative study. Journal of Infrastructure Systems, 16(4), 343-351. https://doi.org/10.1061/(ASCE)IS.1943-555X.0000030

Li, B., Akintoye, A., Edwards, P. J., \& Hardcastle, C. (2005). Critical success factors for PPP/PFI projects in the UK construction industry. Construction Management and Economics, 23(5). https://doi.org/10.1080/01446190500041537

Liu, Junxiao, Love, P. E. D., Smith, J., Matthews, J., \& Sing, C.-P. (2016). Praxis of Performance Measurement in Public-Private Partnerships: Moving beyond the Iron Triangle. Journal of Management in Engineering, 32(4), 04016004. https://doi.org/10.1061/(asce)me.1943-5479.0000433

Liu, Junxiao, Love, P. E. D., Smith, J., Regan, M., \& Davis, P. R. (2015). Life Cycle Critical Success Factors for Public-Private Partnership Infrastructure Projects. Journal of Management in Engineering, 31(5), 04014073. https://doi.org/10.1061/(asce)me.19435479.0000307

Liu, Junying, Meng, F., \& Fellows, R. (2015). An exploratory study of understanding project risk management from the perspective of national culture. International Journal of Project Management, 33(3), 564-575. https://doi.org/10.1016/j.ijproman.2014.08.004

Liu, Z., Lu, Y., \& Peh, L. C. (2019). A review and scientometric analysis of Global Building Information Modeling (BIM) Research in the Architecture, Engineering and Construction (AEC) industry. In Buildings (Vol. 9, Issue 10). https://doi.org/10.3390/buildings9100210

Olawumi, T. O., \& Chan, D. W. M. (2018). A scientometric review of global research on sustainability and sustainable development. In Journal of Cleaner Production (Vol. 183, pp. 231-250). https://doi.org/10.1016/j.jclepro.2018.02.162

Olusola Babatunde, S., Opawole, A., \& Emmanuel Akinsiku, O. (2012). Critical success factors in public-private partnership (PPP) on infrastructure delivery in Nigeria. Journal of Facilities 
Management, 10(3), 212-225. https://doi.org/10.1108/14725961211246018

Osei-Kyei, R., \& Chan, A. P. C. (2015). Review of studies on the critical success factors for public-private partnership (PPP) projects from 1990 to 2013. International Journal of Project Management, 33(6), 1335-1346. https://doi.org/10.1016/j.ijproman.2015.02.008

Osei-Kyei, R., Wuni, I. Y., Xia, B., \& Minh, T. T. (2020). Research Trend on Retirement Village Development for the Elderly: A Scientometric Analysis. Journal of Aging and Environment, 34(4), 402-416. https://doi.org/10.1080/26892618.2019.1707738

Palaneeswaran, E., \& Kumaraswamy, M. M. (2000). Benchmarking contractor selection practices in public-sector construction-a proposed model. In Engineering, Construction and Architectural Management (Vol. 7, Issue 3, pp. 285-299). https://doi.org/10.1108/eb021153

Palaneeswaran, Ekambaram, \& Kumaraswamy, M. M. (2000). Contractor Selection for Design/Build Projects. Journal of Construction Engineering and Management, 126(5), 331339. https://doi.org/10.1061/(asce)0733-9364(2000)126:5(331)

Pellegrino, R., Vajdic, N., \& Carbonara, N. (2013). Real option theory for risk mitigation in transport PPPs. Built Environment Project and Asset Management, 3(2), 199-213. https://doi.org/10.1108/BEPAM-05-2012-0027

Schaufelberger, J. E., \& Wipadapisut, I. (2003). Alternate Financing Strategies for BuildOperate-Transfer Projects. Journal of Construction Engineering and Management, 129(2), 205-213. https://doi.org/10.1061/(asce)0733-9364(2003)129:2(205)

Shen, L. Y., \& Wu, Y. Z. (2005). Risk Concession Model for Build/Operate/Transfer Contract Projects. Journal of Construction Engineering and Management, 131(2), 211-220. https://doi.org/10.1061/(asce)0733-9364(2005)131:2(211)

Smith, N., Zhang, H., \& Zhu, Y. (2004). The Huaibei power plant and its implications for the Chinese BOT market. International Journal of Project Management, 22(5), 407-413. https://doi.org/10.1016/j.ijproman.2003.09.001

Smyth, H., \& Edkins, A. (2007). Relationship management in the management of PFI/PPP projects in the UK. International Journal of Project Management, 25(3), 232-240. https://doi.org/10.1016/j.ijproman.2006.08.003

Tang, L. Y., Shen, Q., \& Cheng, E. W. L. (2010). A review of studies on Public-Private Partnership projects in the construction industry. International Journal of Project Management, 28(7), 683-694. https://doi.org/10.1016/j.ijproman.2009.11.009

Thomas, A. V., Kalidindi, S. N., \& Ganesh, L. S. (2006). Modelling and assessment of critical risks in BOT road projects. Construction Management and Economics, 24(4), 407-424. https://doi.org/10.1080/01446190500435275

Tiong, R. L. K., Yeo, K., \& McCarthy, S. C. (1992). Critical Success Factors in Winning BOT Contracts. Journal of Construction Engineering and Management, 118(2), 217-228. https://doi.org/10.1061/(asce)0733-9364(1992)118:2(217)

Trangkanont, S., \& Charoenngam, C. (2014). Private partner's risk response in PPP low-cost housing projects. Property Management, 32(1), 67-94. https://doi.org/10.1108/PM-02-20130008

Ullah, F., Ayub, B., Siddiqui, S. Q., \& Thaheem, M. J. (2016). A review of public-private partnership: critical factors of concession period. In Journal of Financial Management of Property and Construction (Vol. 21, Issue 3, pp. 269-300). https://doi.org/10.1108/JFMPC02-2016-0011

van den Hurk, M., \& Verhoest, K. (2015). The governance of public-private partnerships in sports infrastructure: Interfering complexities in Belgium. International Journal of Project Management, 33(1), 201-211. https://doi.org/10.1016/j.ijproman.2014.05.005

Wibowo, A., \& Alfen, H. W. (2013). Fine-tuning the value and cost of capital of risky PPP infrastructure projects. Engineering, Construction and Architectural Management, 20(4), 
406-419. https://doi.org/10.1108/ECAM-11-2011-0097

Xu, Y., Yeung, J. F. Y., Chan, A. P. C., Chan, D. W. M., Wang, S. Q., \& Ke, Y. (2010). Developing a risk assessment model for PPP projects in China-A fuzzy synthetic evaluation $\begin{array}{llll}\text { approach. Automation in } \quad \text { Construction, } & \text { 929-943. }\end{array}$ https://doi.org/10.1016/j.autcon.2010.06.006

Ysa, T. (2007). Governance forms in urban public-private partnerships. International Public Management Journal, 10(1), 35-57. https://doi.org/10.1080/10967490601185724

Zayed, T. M., \& Chang, L.-M. (2002). Prototype Model for Build-Operate-Transfer Risk Assessment. Journal of Management in Engineering, 18(1), 7-16. https://doi.org/10.1061/(asce)0742-597x(2002)18:1(7)

Zhang, X. (2004a). Concessionaire Selection: Methods and Criteria. Journal of Construction Engineering and Management, 130(2), 235-244. https://doi.org/10.1061/(asce)07339364(2004)130:2(235)

Zhang, X. (2004b). Improving Concessionaire Selection Protocols in Public/Private Partnered Infrastructure Projects. Journal of Construction Engineering and Management, 130(5), 670679. https://doi.org/10.1061/(asce)0733-9364(2004)130:5(670)

Zhang, X. (2005). Critical Success Factors for Public-Private Partnerships in Infrastructure Development. Journal of Construction Engineering and Management, 131(1), 3-14. https://doi.org/10.1061/(asce)0733-9364(2005)131:1(3)

Zhao, X., Zuo, J., Wu, G., \& Huang, C. (2019). A bibliometric review of green building research 2000-2016. In Architectural Science Review (Vol. 62, Issue 1, pp. 74-88). https://doi.org/10.1080/00038628.2018.1485548

Zheng, C., Ning, Y., Yuan, J., Zhao, X., \& Zhang, Y. (2020). Partnering research within the construction industry (1990-2018): A scientometric review. In International Journal of Technology Management (Vol. 82, Issue 2, pp. 97-131). https://doi.org/10.1504/IJTM.2020.107858

Zheng, L., Chen, K., \& Lu, W. (2019). Bibliometric Analysis of Construction Education Research from 1982 to 2017. Journal of Professional Issues in Engineering Education and Practice, 145(3). https://doi.org/10.1061/(ASCE)EI.1943-5541.0000412 